\title{
Clinical Presentation of Patients on a Chronic Hemodialysis Program
}

\author{
Tanja Boljevic ${ }^{1,2}$ and Damir Pelicic ${ }^{1,2 *}$ \\ ${ }^{1}$ Clinical Center of Montenegro, Podgorica, Montenegro \\ ${ }^{2}$ University of Montenegro, Faculty of Medicine, Podgorica, Montenegro
}

*Corresponding author: Damir Pelicic, Center for Science, Clinical Center of Montenegro, Podgorica, University of Montenegro,

Faculty of Medicine, Podgorica, Ljubljanska bb, Podgorica 20000, Montenegro

\begin{tabular}{|c|c|}
\hline ARTICLE INFO & ABSTRACT \\
\hline Received: May 10, 2021 & $\begin{array}{l}\text { Chronic renal failure (CKD) is an independent risk factor for functional impairment, } \\
\text { and decreased functionality is associated with adverse outcomes, including increased }\end{array}$ \\
\hline Published: 幽 May 25, 2021 & $\begin{array}{l}\text { mortality and hospitalization. Long-term hemodialysis treatment is associated with the } \\
\text { appearance of new disorders caused by the dialysis procedure itself. In this paper, we }\end{array}$ \\
\hline
\end{tabular}

Clinical Presentation of Patients on a

Chronic Hemodialysis Program. Biomed

J Sci \& Tech Res 36(1)-2021. BJSTR.

Keywords: Hemodialysis; Clinical Presentation; Complications; Chronic kidney Disease

MS.ID.005796.

\section{Mini Review}

Chronic renal failure causes dysfunction of all organ systems. Although hemodialysis treatment reduces the incidence and severity of these disorders, this treatment does not completely correct the disorders caused by chronic renal failure. Dialysis treatment was started in European countries in the late 1950s and early 1960s, and doctors who started using these methods founded the European Dialysis and Transplant Association (EDTA) in 1964 [1], and the European registry was named ERA-EDTA (Europen Renal Association) [2]. Hemodialysis treatment in Montenegro began on June 18, 1979 at the hemodialysis center in Podgorica, and in 1998 there were seven centers, where about 170 patients are treated, and each year about 50 new patients require the start of hemodialysis treatment. Hemodialysis therefore achieves a better quality of life for these patients [3]. Today, over a million patients with end-stage renal disease are treated worldwide with one of the methods to replace kidney function. The National Kidney Foundation of America (NKF) and the EBPG (European Best Practice Guideline) have published a number of recommendations, such as recommendations for the adequacy of hemodialysis (hemodialysis dose) [4].

\section{Cardiovascular System Disorder}

Patients with end-stage renal disease have a significantly higher incidence of cardiovascular disease than the general population. Cardiovascular mortality in patients on hemodialysis is 5-15 times higher than in patients without kidney disease [5]. Half of the deaths on hemodialysis are due to the existence of coronary heart disease. Systemic Arterial Hypertension occurs in $80 \%$ of patients with end-stage renal disease. Hypertension is the dominant cause of morbidity and mortality in dialysis patients $[6,7]$. Mean arterial pressure was determined by values of minute volume and peripheral vascular resistance. Hypervolemia is responsible for the increase in minute volume, which is based on a positive salt and water balance, which is explained by the role of the renin-angiotesin-aldosterone system, and which continues to function even in circumstances of significantly reduced nephron mass. The ratio of local vasodilators and vasoconstrictors, increased serum concentration of parathormone, acting on the metabolism of endothelium and smooth muscle also contribute to the increase of peripheral vascular resistance. About $85 \%$ of patients with "volume-dependent hypertension" have normal blood 
pressure after hemodialysis. Anemia, hypervolemia, metabolic and electrolyte disorders, hyperparathyroidism are factors that accelerate myocardial fibrosis, dilatation of the heart cavities leading to heart failure [8].

Pericarditis occurs in patients with terminal renal failure in 35$60 \%$, and clinically significant effusions are not registered in more than $15 \%$ of patients $[9,10]$. Myocardial hypertrophy and dilatation are found in $70 \%$ of hemodialysis patients. Left ventricular hypertrophy is thought to be a compensatory response to its increased hemodynamic load. The most well-known cause of left ventricular hypertrophy in patients with uremia is hypertension. Chronic anemia strongly correlates with the degree of left ventricular hypertrophy, and correction of anemia leads to regression of these changes [11]. Heart failure is characterized by the inability of the heart to satisfy the metabolic needs of the organism with its pumping function in proportion to the current requirements. It manifests clinically as acute heart failure of the left (rarely right) heart, or as chronic-congestive heart failure. Systolic dysfunction as a cause of heart failure is present in $15 \%$ of undialized and $35 \%$ of dialyzed patients. Almost half of these patients also have left ventricular hypertrophy. Ischemic heart disease is in $80 \%$ of cases in patients who start dialysis treatment, and with the duration of hemodialysis, ischemic heart disease develops in those who have not had it before. Ischemic heart disease is the direct cause of death in hemodialysis patients in $10-15 \%$ of deaths, and the same is the frequency of acute myocardial infarction in patients with ischemic heart disease. Cardiac arrhythmias and conduction disturbances occur much more frequently during hemodialysis than in nondialysis patients, studies have shown [12]. They are recorded in almost $75 \%$ of cases if monitored by hourly holter monitoring.

Their sudden and usually short-lived appearance makes them more difficult to diagnose. The most common cause is a disturbance in the concentration of electrolytes in the serum during hemodialysis. Systemic hypotension is rare in patients who are in the pre-hemodialysis phase. Its frequency on hemodialysis is 25$35 \%$. The essence of gradual or sudden drops in arterial tension can be explained by inadequate compensatory venous inflow after ultrafiltration. Infectious endocarditis is common (5\%) in hemodialysis patients but is rarely diagnosed. The occurrence of acute endocarditis is rare, but the occurrence of subacute endocarditis is more common in patients on hemodialysis. Metastatic soft tissue calcifications are closely related to disorders of phosphate, calcium, magnesium metabolism and chronic metabolic acidosis [13]. These calcifications occur with pronounced hyperparathyroidism, poor control of phosphatemia.

\section{Gastrointestinal Disorders}

The most common manifestations of uremia are: persistent anorexia, nausea, vomiting, uremic fetus, mucosal ulcers, gastrointestinal bleeding. Anorexia, nausea, vomiting in inadequate dialysis, frequent gastritis, intestinal wall edema, diverticulosis and diverticulitis, ascites, gastrointestinal bleeding also occur in dialysis patients. Later endoscopic studies of dialysis patients showed pathological findings in $20-75 \%$ of patients.

\section{Respiratory Disorders}

Pleural effusion and hemorrhage in the pleura often occur in these patients. Potentiated pulmonary fibrosis in patients with chronic renal failure, as well as metastatic lung calcification, may have a long-term pathological effect on lung diffusion capacity and other pulmonary functions.

\section{Disorders of the Bone System}

A systemic bone disease that develops during chronic kidney failure is called renal osteodystrophy. There are three groups of renal osteodystrophy: hyperparathyroidism, uremic osteodystrophy with reduced bone turnover-osteomalacia and adynamic bone disease, mixed uremic osteodystrophy with a combination of hyperparathyroidism and uremic osteodystrophy. The basis of renal osteodystrophy is the pathological metabolism of vitamin D, which leads to hypocalcemia, increased secretion of parathyroid hormone, which corrects hypocalcemia by its effect on the skeletal system. Secondary hyperparathyroidism occurs in chronic renal failure as a consequence of metabolic and endocrine disorders and leads to increased synthesis and secretion of parathormone [14]. This disorder is a common complication, especially in patients who are on hemodialysis for a long time. The main factors that lead to increased secretion of parathormone are: hypocalcemia (the main cause), Yamamoto et al. hyperphosphatemia; decreased bone response to parathyroid hormone; impaired vitamin D metabolism; calcitriol resistance [15]; decreased renal parathyroid hormone breakdown; abnormal regulation of parathormone release by calcium ions. In chronic renal failure, Clotho expression is reduced [16]. Klotho is a renal hormone that plays an important role in phosphate metabolism and has an anti-inflammatory role [17]. As HBI's production is reduced, so is its function.

\section{Endocrine Disorders}

The function of a number of endocrine glands may be impaired by an inadequate concentration of circulating hormones on target tissues. Hormone production may be inadequate due to direct toxic damage to the endocrine glands by uremic toxins or insufficient production or degradation of certain hormones in the kidneys. The most common endocrine disorders are: sexual dysfunction, amenorrhea, sterility, hyperprolactinaemia, hyperinsulinemia, growth and developmental disorders with the mentioned hyperparathyroidism.

\section{Neurological Disorders}

Disorders of the central and peripheral nervous system are especially pronounced in uremia. Correction of anemia in these 
patients leads to a dramatic improvement in symptoms by the central nervous system. The most specific neurological disorders in patients on hemodialysis are: disequilibrium-confusion, disorientation, urge to vomit, vomiting, headache, convulsions; dialysis dementia - speech disorder, convulsions and even death. The occurrence of chronic subdural hematoma is a common finding.

\section{Hematological Abnormalities}

\section{Leukocyte Abnormalities}

Another leading cause of death in dialysis patients is infection, immediately after cardiovascular disease. The number of total white blood cells is normal in uremic patients. Dialysis impairs phagocytic function leading to a weaker acute immune response.

\section{Hemostasis Disorder}

In such patients, this is a common occurrence and leads to a tendency to bleed and bruise. The most common and most serious are spontaneous bleeding from the digestive tract, bleeding into the pericardium, and especially intracranial bleeding in the form of subdural or cerebellar hematoma. Nitrates with long and short elimination half-lives are used as anticoagulant for performing extracorporeal dialysis.

\section{Anemia}

In patients with chronic renal failure, normocytic, normochromic anemia is regularly present, which significantly contributes to the symptoms of chronic renal failure. It is usually seen when the JGF value falls below $30 \mathrm{ml} / \mathrm{min}$ and the creatinine increases to about $265 \mu \mathrm{m} / \mathrm{l}$. Hematocrit progressively falls below $15-20 \%$ and in the absence of bleeding. The severity of anemia usually corresponds to the degree of azotemia.

\section{Conflict of Interest}

The authors declare no conflict of interest.

\section{References}

1. Locatelli F, Pedro Aljama, Peter Bárány, Bernard Canaud, Fernando Carrera, et al. (2004) Revised European best practice guidelines for the management of amaemia in patients with chronic renal failure. Nephrol Dial Transplant 19 (2): 1-47.

\section{ISSN: 2574-1241}

DOI: 10.26717/BJSTR.2021.36.005796

Damir Pelicic. Biomed J Sci \& Tech Res

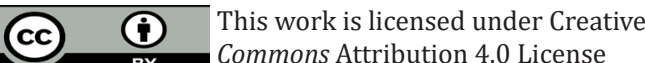

Submission Link: https://biomedres.us/submit-manuscript.php
2. Lebedo I, Kessler M, Wim nav Biesen, Wanner C, Wiecek A, et al. (2001) Initation of dialysis-options from an international survey: Report on the Dialysis Opinion Symposium at the ERA-EDTA Congress, 18 Septembar 2000, Nice. Nephrol Dial Transplant 16: 1132-1138.

3. Ratković M (2002) Procjena kvaliteta liječenja bolesnika sa terminalnom bubrežnom insuficijencijom hemodijalizama. Doktorska disertacija, Med fak Univ Beograd.

4. Stosevic M (2002) Uporedna analiza indeksa adekvatnosti dijalize upotrebom kliničkih parametara pri raznim nivoima dijaliziranosti kod bolesnika na hemodijalizi. Doktorska disertacija, Med fak Univ Beograd.

5. Poskurica M (1998) Etiopatogeneza i učestalost kardiovaskularnih bolesti u terminalnoj insuficijenciji bubrega, Novine u nefrologiji 3: 1-15.

6. Fernandez JM, Carbonell ME, Mazzuchi N, Petruccelli D (1992) Simultatenous analysis of mortality and morbidity factors in chronic hemodialysis patients. Kidney Int 41: 1029-1034.

7. Ritz E, Koch M (1993) Morbidity and mortality due to hypertension in patients with renal failure. Am J Kidney dis 21: 113-118.

8. Greaves SC, Gamble GD, Collins JF, G A Whalley, D N Sharpe, et al. (1994) Determinant of left ventricular hypertrophy and systolic dysfunction in chronic renal failure. Am J Kid Dis 24: 768-776.

9. Foley RN, Parfey PS, Harnett JD (1992) Left ventricular hypertrophy in dialysis patients. Semin Dial 5: 34.

10. Mimran A (1992) Renal effects of antihypertensive agents in parenchimal renal disease and renovascular hypertension. J Cardiovasc Pharmacol 19(6): 45-50.

11. Lazarus JM, Bradley MD, William FO (1996) Haemodialysis. In: Brenner MB, Rector FC (Eds.)., The Kidney. W. B. Saunders, pp. 2425-506.

12. Locatelli F, Bommer J, London GM, A Martín-Malo, C Wanner, et al. (2001) Cardiovascular disease determinants in chronic renal failure: clinical approach and treatment. Nephrol Dial Transplant 16: 459-468.

13. Liach F, Bover J (1996) Renal osteodystrophy. In: Brener BM (Edt.)., Brener -Rectors the Kidney. W B Saunders comp, Philadelphia, London, Toronto, pp. 2187-2273.

14. Michel K (1997) Europen best practice guidelines for haemodialysis (part 1); 2002. Poskurica M. Poremećaj metabolizma kalcijuma i fosfata u hroničnoj bubrežnoj insuficijenciji. Acta Fac Med Naiss 1: 17-26.

15. Ming C (2012) The emerging role of Klotho in clinical nephrology. Nephrol Dial Transplant 27(7): 2650-2657.

16. Izquierdo M, Perez Gomez M, Sanz A (2012) Klotho, phosphate and inflammation/ageing in chronic kidney disease. Nephro Dial Transplant 27: 6-10.

17. Albertazzi A, Battistel V, Libertato L (1998) Efficacy and tolaribility of recombinant treatment in pre-dialysis patients: Results of a multicenter study. Int J Organs 21: 12-18.

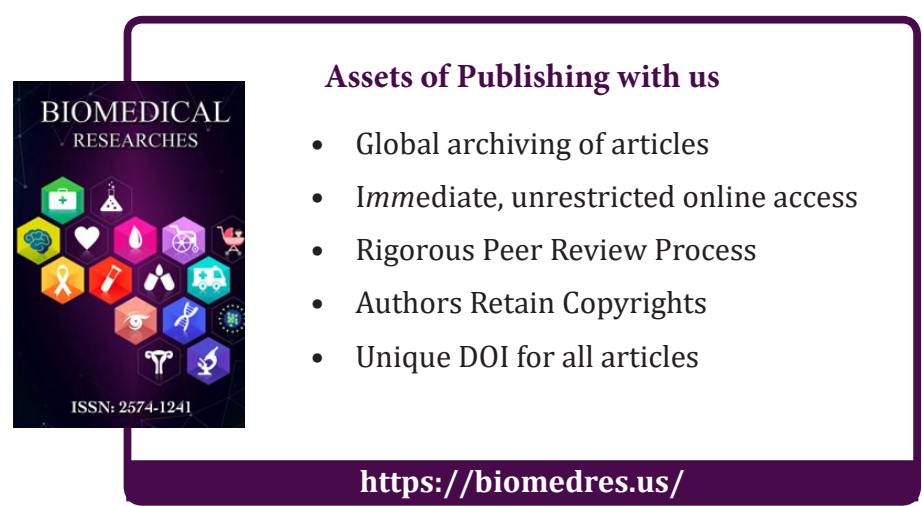

